\title{
Consumption of Digital Media by Children and pre-Teenagers in Catalonia, Spain ${ }^{1}$
}

\author{
Hedabide digitalen kontsumoa Kataluniako \\ (Espainia) haur eta nerabeen artean
}

\section{Consumo de Medios Digitales por niños y preadolescentes en Cataluña, España}

\section{Ruth S. Contreras Espinosa ${ }^{2}$ \\ Irene García Medina ${ }^{3}$ \\ Zahaira González ${ }^{4}$}

\section{zer}

Vol. 20 - Núm. 39

ISSN: 1137-1102

e-ISSN: 1989-631X

DOI: 10.1387/zer.15529

pp. $145-162$

2015

Recibido el 3 de enero de 2014, aceptado el 2 de octubre de 2015.

\begin{abstract}
The focus of this study is patterns of use of digital media, which are the most popular platforms and what control that parents impose on the consumption of digital media. We analyzed children aged between 7 and 10 years old and pre-teenagers aged between 11 and 12 years old. These groups are those who influence the medium-term trends. The results show that digital media are present in the everyday life of children, who regularly consume their preferred contents. They can be powerful if they can recognize and use their power in this culture of convergence as users.
\end{abstract}

Keywords: Consumption, new media, children, pre-teenagers, Catalonia.

\section{Laburpena}

Ikerketa honen helburua hedabide digitalen erabilera-patroia, plataforma erabilienak, eta gurasoek ezartzen dituzken kontrolak ezagutzea da, 7 eta 10 urte arteko haurren eta 11 eta 12 urteko nerabeen artean. Hauek, epe ertainean joera berrien eragin handiena jasoko duten

\footnotetext{
${ }^{1}$ Héctor Navarro-Güere también forma parte del equipo que ha llevado a cabo este trabajo.

2 University of Vic - Central University of Catalonia, ruth.contreras@uvic.cat

3 Glasgow Caledonian University, iga2@gcu.ac.uk

4 University of Vic - Central University of Catalonia, zahairaf.gonzalez@uvic.cat
} 
taldeak dira. Emaitzek adierazten dute hedabide digitalak haurren eguneroko bizitzan presente daudela, eta eduki gogokoenak ohiko moduan kontsumitzen dituztela. Emaitza hauek garrantzi handikoak izan daitezke, erabiltzaile moduan konbergentzia-kultura honetan duten boterea ezagutzen eta erabiltzen bada.

Gako-hitzak: Kontsumoa, hedabide berriak, haurrak, nerabeak, Katalunia.

\section{Resumen}

El objetivo este estudio es conocer los patrones de uso de los medios digitales, las plataformas más usadas y entender los controles parentales que se ejercen sobre niños de entre 7 y 10 años y preadolescentes de entre 11 y 12 años, los grupos que serán influenciados a medio plazo por las nuevas tendencias. Los resultados muestran que los medios digitales están presentes en la vida cotidiana de los niños, que consumen regularmente sus contenidos preferidos. Estos resultados pueden ser de gran alcance si es posible reconocer y utilizar su poder como usuarios en esta cultura de la convergencia digital.

Palabras clave: Consumo, nuevos medios, niños, preadolescentes, Cataluña. 


\section{Introduction}

During the past 20 years, the audio-visual sector has been subject to an important transformation, both in terms of what is on offer and its consumption, in terms of digital convergence. The convergence demonstrates the coexistence of the new digital media with a culture of participation, led by users' communities with a frantic activity. In this context, the fragmentation of the users is increased, because the typology of content platforms has changed to a significant extent.

The contents have multiplied and hybridized, and now they are available on different devices. The media industry is in a moment of evolution and represents a cultural change, since it encourages the consumers to seek for new information and to establish connections between media contents. Children represent an important role, and this is known by the producers of contents, agencies, etc., since all of them benefit from understanding the use and the consumption of the media across the studies of users. And though some behaviors of the children are practically obvious, others might surprise especially in the habits of the consumption of media or contents.

In this panorama, the platforms of contents have changed and on the Internet we can find circulating with diverse facility flexible content for children and teenagers. The progressive facility of use of technological tools modifies the components: the facility of access, the improvement and facilitation of his conditions of utilization and the best integration of each component.

The digital media convergence directly influences the way in which the digital generation uses and consumes the new media on a daily basis to communicate, to be educated and to amuse themselves. Social networks, on the other hand, have turned into an indispensable tool for children and teenagers because they use platforms to construct communities, giving them the possibility of expanding themselves beyond their everyday life.

In this paper, we show the attitude and the consumption by children and preteenagers from Catalonia, Spain, as cross-media users. The study analyzes the use, attitude and consumption of the new media, showing the multiple circumstances and technological determinism that exist in this media ecosystem, an area with little current research, especially about children and pre-teenagers between 6 and 12 years old.

\section{State of the art}

From investigations, we can observe the change in the consumption of media and contents by Spanish children and teenagers that has happened in the last years. Studies from Livingstone \& Brake, 2010; Livingstone, et al. (2011), García-Jiménez, López \& García (2013) or from Valkenburg, P. M. \& Peter, J. (2011) show an interest in understanding the profile and motivations of users, especially how teenagers use social networks and platforms. However the profile of children in Catalonia is not being investigated in depth yet. There are only a few studies centered on the consumption of digital media by children and teenagers. The majority of these studies focus on those above 14 years old and are generally concerned on the consumption of media in general. 
In Catalonia, and also in Spain, in spite of the Internet consolidation, television continues being the most popular media of communication. The users still spend more hours in front of the TV, 88.6\%, than listening to the radio or surfing on the Internet (AIMC-EGM, 2012), but the experience of entertainment is changing and diversifying due to smartphones or tablets, especially in the case of the children and teenagers.

Television constitutes the principal media that provides audio-visual contents to the Catalan population. The age of the user says much about the consumption, for example, teenagers dedicate their evenings to out-of-school activities whereas small children dedicate their time to the TV.

In this respect, the report of Perez Tornero and Pulido (2012) mentions that Catalan children dedicate an average of at least 2 hours per day on weekdays and at least 3 hours during weekend days to watching television. The majority watch television without family supervision, 59\% of children between 6 and 9 years. On the other hand, young people start using the television via the Internet, with a major trend towards the consumption of TV series in streaming or for downloads, and $20 \%$ access television in this way.

TV streaming is becoming widely used. The platforms of YouTube, Metacafe, Vimeo, or even the official websites of the principal television channels provide an alternative to the traditional scheme of programming. Nowadays, all the national TV channels have negotiated with YouTube to place their contents on the Network ( $\mathrm{Ru}-$ ano, 2010), and this does not means that they eliminate the formats of previous TV, but means that they combine them with new forms to give place to hybrid formats that the youngest begin to consume using one 'second screen' to complement the contents of the TV.

Spanish children and teenagers use the Internet for almost 2 hours a day. From the point of view of the young people, this is to the detriment of other activities: $52.4 \%$ of them recognizes that their Internet use takes time away from their from school activities. 33.4 total \%, 40,9\% girls and $32.4 \%$ boys, they confirm that they spend time watching television and $23.6 \%$ in video games, $20.2 \%$ the girls and $26.3 \%$ the boys (Bringué \& Sábada, 2009).

The mobile phone is one of the most wanted screens in the under 18 age group. This can be due to the independence and the mobility that the young people perceive because they consider this device as a really personal screen. Bringué and Sádaba (2011) mention that the penetration of the mobile phone between in this group of age passes $90 \%$ from 13 years old. But also in this case the information shows differences depending on if the young people are or not users of social networks.

Speaking about contents, children demonstrate significant preferences for different kinds of programs that are usually available on TV. Many fiction series begin on the television screen and continue in web pages, note-pads, wikis, apps, cinema, etc. Or even, they start off web and finish in the televisions. This means that a content can be consumed by children at the same time in different platforms and screens. According to Bringué and Sádaba, fiction movies are the principal preference of the under 18 years old without differences depending on gender, and in TV series, the number of fans grows in case of the girls.

Sport is a favorite content for $40 \%$ of the young people, boys $63 \%$ and $18 \%$ girls, so are cartoons. The most prominent information is that the above mentioned interest 
decreases with the age and is replaced with movies and series. Programs those that are based on game shows and competitions are among the favorite programs for a third of young people. Competitions are slightly more popular among girls.

$33 \%$ express a preference for reality shows: girls are 20 points over the boys. Documentaries and news programs: a quarter of young people are interested in this, and it is especially popular among boys. Bringué and Sádaba (2011) also mention that Spanish young people consume music, games, humor, sports and news. Secondly, educational and cultural contents, and whose access is specially linked to the development of school tasks.

The Internet contents and in video games are most popular amongst children and pre-teenagers. To the question 'If you had to choose between Internet or mobile, Internet phone or video games, Internet or the television', the most popular response by the children is 'Internet or video games' (Bringué \& Sádaba, 2011).

One in 10 consume educational or cultural contents. The preference and frequency of use is related to the age and the gender of the users of the Network. Up to 12 years, young people mainly search for contents related to games and pages of educational type. The access to the rest of contents grows as increases the age of the users.

By gender, the girls have a major preference for musical, educational contents, and the programming in television. The boys, nevertheless, clearly prefer sport, games, contents related to software and computing, and humor. There is very significant his major preference for the adults' contents: $22 \%$ opposite to $2 \%$ of the girls. The popularity of educational and cultural content and contests is not affected by gender (Bringué \& Sádaba, 2011). Blogs and the world of social networks are some of the platforms more used by young children in the Internet. The reasons for using Social Networks are different, especially for teenagers. These is summarized in the following table.

The most visited contents are music, sports or games which are also the most frequent subject matter of their web pages or blogs.

To tell their own personal story, like a diary, is the preference for 1 of every 4 of the creators and is clearly a feminine preference (32\%). Finally, Bringué and Sádaba mention that $8 \%$ of minors state that they create contents for an adult audience. The reasons why users begin to be the creators of the contents are: the possibility of expressing their opinions and the fact of being able to share information with people they know.

To create digital contents allows them to share their tastes -clearly a feminine option-, to expose themselves to the public and also to make new friends. Finally, the advanced users of Social Networks are the most likely to create their own contents related to music and personal stories. By gender, girls generally prefer to create music or to tell personal histories. Boys are generally interested in music, sports or games.

Also it is important to outline that $17 \%$ of the teenagers admit to visit sites with adult oriented contents (Bringué \& Sádaba, 2011).

In Catalonia teenagers prefer the platform Facebook $(75.2 \%)$, whereas in the rest of autonomous communities of Spain. The teenagers prefer Tuenti $(88.5 \%), 48 \%$ of the Catalan teenagers have 'a profile' in a social network whereas $33 \%$ in two Social Networks. $57 \%$ supports an active profile whereas $35 \%$ mentions to be 'active' in 'two profiles'. As for the activity, $39 \%$ of the teenagers view their profile several 
times a day and $27 \%$ does it once a day. Depending on the gender, the option 'several times a day' is selected by the group of the girls (42.9\%) whereas in the boys the consultation is minor $(34.5 \%)$. This study concludes that girls mainly use Social Networks (Sanchez \& Fernández, 2010).

Table 1. Use of Social Networks between young people (under 18 years old) in Spain.

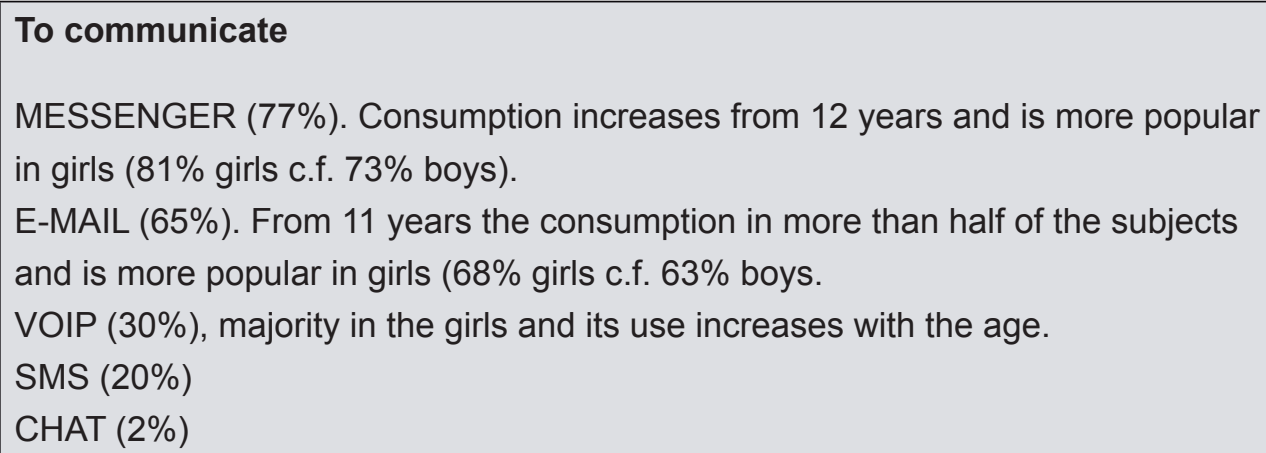

\section{Finding information}

Use of a search engine (76\%).

A total of 7 between 10 young people admit the utilization of services that allow them to download music, movies and IT programs.

\section{File Sharing}

They use services to share with other users photos and videos: YouTube or Flickr (56\%). Blogs (25\%) and photoblogs (33\%).

\section{Leisure}

They use Internet to take part in games online activity with clear masculine preference $(60 \%), 7$ of every 10 boys use services of game in network: games of careers, of strategy, of sports and RPG. Girls like social games. The principal reason of use is the possibility of developing spaces and playful times with his/ her friends.

Based on Bringué \& Sádaba, 2011.

As for games consoles, the most popular are Wii and Nintendo DS. This is due to their rising percentage of penetration in the market and the different game experiences that they offer to users. The platforms YouTube, MySpace, Vimeo, or the official web sites of the principal Channels of television are most visited by the Catalan children (Navarro et al. , 2011). As for the differences by gender, the daily 
visits of the girls include web spaces as personal pages and chats, and they visit them in percentages greater than that of boys. On the other hand, they visit web sites related to games, sports or downloads on a daily basis much more than girls (AIMC-EGM, 2011).

Finally, regarding on-line safety for teenagers, the study from Garmendia, et al. (2011) shows that personal information is given away to an increasing extent. 1 in 10 ten teenagers are said to suffer from racism, promotion of anorexia and bulimia and same study shows that age is also an important factor of exposition to the pages promoting these things. $22 \%$ of those younger than 15 years old are said to have access to images of a sexual nature on the Internet. The frequency of access to this sort of contents increases with age. Also, this sort of inappropriate content causes more damage with decreasing age of the child (Garmendia et al., 2011). Parental control has a very important role regarding all of these inappropriate contents.

In Catalonia, $37 \%$ of the Catalan parents say they limit access to the Internet of their children by time slots, whereas $35 \%$ chooses to limit the time of connection. In both cases they refer to fixing the duration of access to the Internet to 1 hour, as in the case of the television (Roca, Aranda \& Sánchez, 2012). The study shows that $41.4 \%$ of homes where the child is a boy the time of connection is limited, against $25.9 \%$ of the homes where is a girl. And as the age of the child increases, the difference increases (Roca, Aranda \& Sánchez, 2012). The homes consulted for the study therefore show that parents are more concerned about the time that the sons dedicate to the Internet, rather than that of their daughters.

\section{Research methodology}

The study has been carried out from May-June, 2012, and in 3 phases: a) Analysis of documentary information; b) Design and execution of the field study; c) Conclusions of the study. As methodology of investigation, 2 discussion groups were used, and groups were divided according age, range and gender. The focus groups were done for 7-12 children, with duration of 1:30 hour. They were carried out in primary schools in the city of Vic. The sessions were coordinated in the form of focus groups by a specialist. Children were randomly chosen and 40 young people participated: 24 children and 16 pre-teenagers. The total by gender is 13 girls and 11 boys. In the pre-teenage group, 8 were male and 8 were female. All of them could be considered middle class by local standards. The focus groups were conducted in Catalan.

Age is important to understand the effect on the use and the consumption of the media. The attitude changes depending on age and marks the level in which every individual interacts with the media. For this reason, the results have been divided in two groups: Children from 7 to 10 and pre-teenagers from 11 to 12 years old. Priority has been given to these groups because they show the influence of medium-term trends, and they are the users who have socialized with a series of platforms that did not previously exist. 
These are the questions that we try to answer:

1. With what frequency do children use digital media?

2. How many children have access to the mobile media, as smartphones and tablets?

3. What contents do they consume?

4. What platforms are more popular between the children?

5. What control that the parents exercise in their children's consumption of media inside the home?

6. Are there differences by gender in the habits of use of the media?

Since the current study explores media use among children from 7 to age 12, most findings can't be directly compared with previous Catalan results (Perez Tornero \& Pulido, 2012; Bringué \& Sábada, 2009; Sanchez \& Fernández, 2010; AIMC-EGM, 2011; Roca, Aranda \& Sánchez, 2012), which included children and teenagers from 10 to age 18 .

\section{Results}

\subsection{Girls}

Today a substantial proportion of the time that young children spend with screen media is spent with digital media including computers, hand held and console video game players, and other interactive mobile devices such as cell phones, iPods, and tablet devices. The girls tend to watch TV between 2 and 3 hours every day. Generally, they use the conventional TV but also they use streaming, though watching programs via streaming is used is half the time of regular TV. This group in addition uses video game consoles such as Wii, Play Station or Nintendo DS at least 2 times a week. The latter with a major use between girls of minor age. MP3/ MP4 players are in use in some cases, but these are in the habit of being replaced with mobile phones, which have gained area. In this group, a PC or laptop is also generally used.

PCs are used every day and for a duration of 2 hours per day, whereas the mobile phone is a device that is in use every day for a duration of 3 hours per day. In relation to other digital media, the use of the press or of the radio is not detected. Girls mentioned to have access to smartphones or tablets when their parents lent them the devices or if they receive them as a gift. In general they are owners of a smartphone if it is passed on and only in a couple of cases they have access to a tablet when someone of the family allows them to use it. In these cases the principal use that they provide to the device is 'to play' with some apps. In summary, the use of mobile devices within this group is minimal, only WhatsApp and Line are used. 
The contents that they consume via TV, include cartoons, movies and series without any preference of languages, Spanish or Catalan- which are watched during leisure time, on weekdays or during the weekend. They also consume fixed images to a large extent and all kinds of videos and or audio-visual productions. In the focus group they mention that they use Internet to watch at programs that their parents would not allow them to watch via TV. Also they are in the habit of using Ares or Emule to download content, basically TV series. The download of movies available in the cinema was not mentioned.

Catalan girls appear to be familiar with of all kinds of contents and only their parents or tutors are opposed to this freedom of use. They generally go online via PC with the intention of communicating with their parents or friends, but in addition for leisure activities such as listening to music or to post photographs. They dedicate a large part of their time to social networks, emphasizing the possibility of speaking with their friends to save money because they do not use a telephone line and also they shorten distances. For school based uses, they use Internet in the teaching institutions to access information requested by the teacher and to study in a collaborative or individual form.

The most used space is Wikipedia especially to look for information. They prefer e-books because they say that they can find a specific text quickly. When they are doing homework or other activities in the PC at home, they generally use Open Office or Moodle. The majority keep chat programs open during study time. Some of them look at photos, or the 'Walls' of the people that they know and make comments. They use principally the social network Facebook, but also Messenger, listen to music mainly via Spotify and download music in Ares, while they view videos using YouTube, MySpace, Vimeo or the official web sites of the principal television channels. The youngest girls are those who mention to have an account in Messenger but the trend is changing in favor of Facebook.

The girls who use YouTube recognize that they only look at videos and do not post their own videos, whereas they do post photos on Facebook. The young children frequently play games via Club Penguin and among the older children, the preferences are social games, where friends are online and can help them. FarmVille and CityVille are popular. The girls recognize they should not contact people that they do not know. As for the control that the parents exercise, the girls mention that the parents exercise a more strict control in the use of the TV than in Internet.

The girls mention that the control depends on the day and routine. They do not mention that a strict control exists as for the contents that they consume via the Internet, except in the case of the social network Facebook. Only 2 of every 10 girls comment that their parents do not allow them to create a profile, but this restriction is not applied in the case of Messenger. During the discussion groups, one of the topics more appealing between girls was the way of establishing contact with friends freeing the restrictions of the parents. Apparently the parents exercise most control when the girls use WhatsApp and Line on mobile phones.

The control is related not only to their use, but also with the schedules and time of use. They mention a strict control using prepayment cards to limit usage and restrictions based on days and routines. All these measures are basically are to control expenses. 


\subsection{Boys}

The boys consume traditional TV between 2 and 3 hours every day and they comment that the most used device is the PC computer and the laptop, between 3 and 4 hours per day. At home, the PC is located in general in their room or in the room where they study. Some of them share it with their brothers, the rest of the family and in some cases it is for their exclusive use. Also they comment that they use a computer in school, for school activities. The way in which they use a computer is diverse. They also use it for streaming though the connection can be slow at times. They admit that the television 'à la carte' is an alternative when the television is occupied by the rest of the family, or that they prefer to download series that do not continue in the traditional television or because there is no advertising.

Other device used by children is the video games console (Play Station, PSP, Xbox, Nintendo DS and Wii), they admit to use them in their free time approximately 2 hours and especially in weekends. Also they use Apps and online games to a large extent, mentioning that the use can be double than that of the console. Finally, they use MP3/MP4 players regularly. The smartphone is an object of desire for the Catalan children. Those who have one use it only to communicate in case of emergency, to WhatsApp and Line, and they would use it more if they had sufficient 'credit'.

They use it to listen to music, to record videos and to take photographs. Due to the focus group, it has been noticed that they have access to smartphones or tablets with an Internet connection thanks to their parents, but only 5 of 10 are the owners of a smartphone or tablet that generally are passed on to them. These are in the habit of connecting with Wifi or $3 \mathrm{G}$. The TV contents preferred by the children are series and cartoons, which are watched during their leisure time, on weekdays or in weekend without preference of language -Catalan or Spanish-. The titles of games most played on video games consoles are diverse and they can be role play games, sports or strategy.

There is a certain difference between older children because their preferences in games include action and sport, principally. The contents that they consume via the Internet can be divided in two groups: social Networks and games online. The Internet provides the opportunity to socialize with their friends and even allows children to create their own content, 6 of 10 dedicate their time especially to social games. One of the most popular platforms between children for the study, is Wikipedia. But also they consult others links, as blogs arranged by the teachers. As for the social networks, the young children they have a profile in Messenger and older children have a profile in Facebook.

They listen to streaming music with Spotify and download music with Ares. They watch videos in YouTube principally, and occasionally they do videoconferences with Skype. For homework, they use specific programs like Paint or Photoshop, Word, Power Point and Open Office. Also Moodle as Virtual Learning Environment. Between the younger children, the use of Open Office is less. The parents exercise control on the contents that they watch on TV or Internet. This control is more rigorous on weekdays when the child has lessons, and the type of content that is consumed depends on what the rest of the family wants to see for TV and on the safety of the content for the Internet. 
In relation to the smartphone, its use is restricted not only to calls. The Internet connection to $3 \mathrm{G}$ is also restricted. In the dynamics of group it appears that they are parents who pay the invoices and like that they exercise a certain control of the device. The children mention the fact that the parents try to control the titles of the games played on consoles for example Call of duty, but they always manage to obtain the game from a friend. Only their parents are opposed to their use of and access to the Internet and mobile devices.

\subsection{Pre-teenage Girls}

TV is one of the media that these girls use, especially to watch thematic channels, such as CANAL33 -a Catalan cartoons channel- or Discovery MAX. The consumption ranges from 2 to 3 hours per day. Nevertheless the PC begins to gain popularity, especially due to the Internet being used to look for information, to entertain and socialize, but in addition to carry out their school activities. This explains the daily use for a minimum of 3 hours. They consider that the information in Internet is not limited or manipulated. Between pre-teenagers a daily use of the streaming exists in addition, especially in PC to visualize thematic channels or to listen to music. The young women use video games less than boys alluding to the violence that exists in videogames.

The pre-teenagers have access to smartphones and tablets without parental control. The majority of them connect to the Internet with WiFi, and though in most cases they lack $3 \mathrm{G}$ services, they look for solutions as to use the smartphone of their parents or bigger brothers. The use that this group gives to the devices, basically is to record on video or to obtain photographs to introduce them in Internet - basically Facebook-. The consumption of audio-visual contents from mobile devices is not an activity observed in this group. The users principally use the Internet to for leisure activities, to look for information, to socialize and 'to be available' via the PC.

To connect to the network from a mobile device is one of the things that they wish and value the most because the connection is in real time. This group stands out for the use and consumption of contents in social networks. During the discussion groups, the group commented on the use of the chat principally 'to be with friends' because unlike e-mail, forums or the 'Wall' in Facebook, the conversation does not remain registered. The social networks not only stand out because they displace to the traditional calls, but because it is the way of being in touch with friends. They emphasize the use of Facebook and Twitter in this order. Nevertheless it is not habitual to use Twitter. Email is used only to a small extent.

Though social networks provide the opportunity to socialize, young girls prefer socializing with the friends directly. It is enough to them to look at the photos to know 'how they are going'. Even the networks are important to contact people whom they had lost communication. As observed the younger group, the pre-teenagers neither differ nor give importance to the language that they use: Spanish or Catalan. With regard to consumption of music, Spotify is the most popular. Also they are in the habit of using Ares or Emule to download music, but especially to download TV series. To a lesser extent they mention the Internet to download of movies. As for the use of video games, online use is mentioned and they only like the virtual community games such as Dragon City and in consoles such as Wii. 
The control that the parents exercise in this age is less strict than in children. The impression that the testimonies give is that they have freedom and this freedom is only limited by the disapproval of the parents for watching some specific TV programs. The use of some devices is controlled basically by the expense for Internet connection. The conclusion to which we have come on the basis of the answers of the pre-teenagers, is that Internet is perceived as a free space which little control. Other impression resulting from the study is that this topic has stopped being a priority between parents and children.

\subsection{Pre-teenage Boys}

The majority say they watch TV every day from 2 to 3 daily hours via a traditional TV set, and only 3 out of 10 say they watch the programs using a PC or laptop. They say they watch programs via PC for 3 hours per day on average. Mobile phones are used mainly for receiving calls, and in some cases they mentioned they use Apps and games when they can download them with Wifi at home. They say they play video games for 2 hours per day on average mainly via a games console: Xbox is the most popular, but they prefer online games. In this case 5 of 10 children say they play online games every day.

From the focus groups, it can be deduced that the smartphone is an important device for them for the strong social pressure of possessing such a device, especially a top of the range model. It emerges from focus group discussions that there is a generational technological gap between old and young people emphasizing that on occasions they know more about the technology than their parents. They emphasize in addition the importance of the size of the screens speaking of tablets, especially to improve the legibility.

For them, the use of a computer has an educational purpose, to socialize and for leisure in general. We have to mention that the access to Internet is mentioned as very important due to his immediacy and they value the capabilities of Google and Wikipedia, confirming that they use these spaces all the time. The Internet use is seen as an element that forms part of their lives, they cannot imagine to be without Internet and it concerns them when they do not have access. They use social networks like Facebook and MySpace. Facebook is the favorite because it allows them to be connected to friends and relatives. The majority of times they are connected to people that they know, albeit not very well.

They value the use of social networks, though use of MySpace is minimal. They also like to access to games to be in touch with the friends - Facebook-. They think that their consumption in the web in occasions is excessive but they justify it with the excuse of the peer pressure. They perceive social networks as not being safe sites. With regard to streaming TV, they say they watch CANAL 33's contents and to download basically North American series, they mention Big Bang Theory and Two men and half as examples. They do not mention to prefer contents in Spanish or Catalan though the majority of those that they consume they are titles in Spanish. With the intention of economizing, also they comment that Internet is cheaper than being present at a cinema. YouTube is the platform that they use to view videos, in general, or videos that friends send them. 
Spotify and Itunes are used to listen to music and they share photos via Facebook. For video games they mainly use Xbox, Play Station consoles and they use Apps less often. The control that the parents exercise on the contents that they view in the TV or that they watch in the PC is less rigorous at this age. The control is related to the time of use and not to the contents. In relation to the smartphones, we detected that the use is minimal, is restricted to do calls and sometimes to connect to the Internet. They use WhatsApp and Line. The video games are one of the most controlled elements, independently of their use in computer or consoles and the parents control the time and the contents. The pre-teenagers mention using diverse tactics to evade the control. They mention the use of chat when they should be doing their homework.

As for the differences that exist in the habits of use in the media by gender, the only substantial difference found between Catalan boys and girls is the use of the console video games. Boys are more likely to have ever played a console video game than girls. It is prominent to see that the majority of the girls do not play with games of console. Those girls, who have a console, prefer Wii, mentioning the type of interactivity that the console allows, which might explain a preference to activities that imply a corporal activity. The type of games that they use also change, being those of action, strategy and role preferred of the boys.

Finally, from the focus group is observed that the girls have the idea that computers are 'to do homework' more than the boys.

\section{Discussion}

Both children and young people are born and grow up with IT and therefore its use turns out to be as familiar as the act of learning to write (Contreras-Espinosa et al., 2011). The media literacy begins at a very early age, and the use of screens and devices as the use of multimedia contents increase.

Digital media is part of their lives and become something they use every day. Because of this, Catalan children use a wide range of devices every day and their access to the Internet is not limited only via a PC at home.

The older children (11 to 12 especially) spend more time online, and have more desires and probabilities of using Internet with a mobile phone, whereas the device is a great aspiration between the young children who do not possess a smartphone. Some of the behaviors of the children are almost obvious but others surprise, as for example: to possess a Twitter account due to social pressure, but not to use it habitually, or the lack of preference between contents in Catalan or Spanish language. The digital convergence therefore has concerned directly in the way in which the digital generation uses and consumes the new mass media.

For researchers worried by the impact of multitasking media and how it influences the development of the mind, it is interesting to see the habits in different areas developed by children who use more than one media simultaneously: They do their homework while they chat with friends, or consult Internet and in front of the TV.

But also it is interesting to observe that on occasions, especially the girls assign what particular devices are used for. for example, the PC 'is for homework'.

They are users of social networks on a large scale and it might be said that they exist a direct relation between the available devices with access to Internet and the 
social pressure that the friends exercise. The social networks as an indispensable tool for children and pre-teenagers, have a complex technological and innovative universe; that allows them to construct communities, and gives them the possibility of extending their daily life. And that is because it is not only the space where family and friends are present, but it is also a space with a great diversity where participation increases and consolidates the contents and brands and they incorporate the children in order that they spread and share information.

Table 2. Contents, frequency and use of platforms and social networks.

\begin{tabular}{|c|c|c|c|c|c|}
\hline Gender & Age & Platforms / Frequency & $\begin{array}{l}\text { Social } \\
\text { Media }\end{array}$ & Contents & $\begin{array}{c}\text { Parental } \\
\text { control }\end{array}$ \\
\hline & $7-10$ & $\begin{array}{l}2 \text { or } 3 \text { hours } 1 \text { day } \\
\text { Major use than older, } \\
2 \text { times a weak } \\
2 \text { hours a day } \\
\text { Gain ares, } 3 \text { hours a day }\end{array}$ & 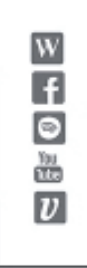 & $\begin{array}{l}\text { TV - Curtoens, } \\
\text { movies or series. } \\
\text { Smartphones to play } \\
\text { with papps. } \\
\text { Imtemet to search } \\
\text { informstion. } \\
\text { Social media to } \\
\text { downlosd music, } \\
\text { view videos. }\end{array}$ & $\begin{array}{l}\text { The parents give } \\
\text { the smarphones as } \\
\text { a gift. } \\
\text { They use the } \\
\text { Intertet of watch } \\
\text { the programs they } \\
\text { are not allowed to } \\
\text { watch on TV } \\
\text { Not srikt coatrol } \\
\text { existe. } \\
\text { Use of schedules. }\end{array}$ \\
\hline & $7-10$ & $\begin{array}{l}2 \text { or } 3 \text { hours a day } \\
2 \text { hours a day, } \\
\text { especially weekends } \\
3 \text { or } 4 \text { hours a day } \\
\text { Only to communicate } \\
\text { in chese of emergency }\end{array}$ & 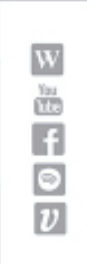 & $\begin{array}{l}\text { TV-Certoens, } \\
\text { series, action \& } \\
\text { sport. } \\
\text { They prefer to play } \\
\text { social games. } \\
\text { Intemet to search } \\
\text { information, play } \\
\text { games co line, } \\
\text { downlosd music, } \\
\text { view videos. }\end{array}$ & $\begin{array}{l}\text { Both calls and } \\
\text { internet } \\
\text { connection are } \\
\text { restricted. } \\
\text { The obtain games } \\
\text { they are not } \\
\text { allowed is have } \\
\text { from a friend. }\end{array}$ \\
\hline & 11-12 & $\begin{array}{l}2 \text { or } 3 \text { hours a day } \\
\text { Use vidoo games less than } \\
\text { boys because the violense } \\
\text { Gain force, } \\
\text { minimum } 3 \text { hours a day } \\
\text { Use to consect with the } \\
\text { group through social } \\
\text { medis }\end{array}$ & $\begin{array}{l}f \\
y \\
0 \\
\text { W }\end{array}$ & 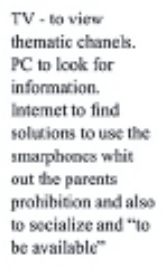 & $\begin{array}{l}\text { They use tablets } \\
\text { and smartphones } \\
\text { whitout } \\
\text { supervision and } \\
\text { no controls are } \\
\text { placed on their } \\
\text { use. } \\
\text { Control less strict } \\
\text { than the children }\end{array}$ \\
\hline & $11-12$ & $\begin{array}{l}2 \text { or } 3 \text { hours a day } \\
2 \text { hours a day, ther prefer } \\
\text { the use of consoles to play } \\
3 \text { hours a day } \\
\text { Siroese social pressure to } \\
\text { use or bave one. But the } \\
\text { use is minimum, only to } \\
\text { do calls and some times } \\
\text { to acess io the internet }\end{array}$ & $\begin{array}{l}0 \\
f \\
0\end{array}$ & $\begin{array}{l}\text { TV to view North } \\
\text { Americen series. } \\
\text { PC only with } \\
\text { edusational purpose. } \\
\text { Imemet is very } \\
\text { important, forms } \\
\text { part of their lives. } \\
\text { Social media to } \\
\text { sharo photos, listen } \\
\text { musis. } \\
\text { They prefere } \\
\text { consoles to play } \\
\text { video games. }\end{array}$ & $\begin{array}{l}\text { The coentrol of the } \\
\text { parents is related } \\
\text { to the time of use } \\
\text { ca not to the } \\
\text { contents. }\end{array}$ \\
\hline
\end{tabular}

The table was created by the authors of this paper.

The use of social networks by children should have direct implications on the control of the information that they share at a personal level. These are places where there is concern about the way teens interact with others and where they share information about their lives (Maden et al., 2012). Nevertheless the Catalan parents 
seem to be more preoccupied by the time that is spent and not for the content that is shared. This suggests that parents and children need support and advice on the control of personal information. An excessive confidence on Internet can bring risks, for example, of cyber-bullying or the access to inappropriate contents by young people.

It is nevertheless surprising to think that boys are more conscious than girls on the insecurity of the social networks. As for the differences that exist in the habits of use in mass media by gender, we can say that in these ages there are very few differences, as is mentioned in the report Zero to Eight (Rideout, 2011). In early ages, only there are substantial differences in cases as income or education of the parents. The substantial difference is in the use of the video games. The girls are not interested in violent games, and this could explain the interest of girls in playing (Grodal, 2000) only in certain kinds of games.

On the other hand, young girls use video games less the than boys and one of the reasons can be that the strategies of marketing are centered basically on men (Ivory, 2006) and in an infantile public, which explain why the girls that play say to do it in social media networks and not being seduced by the existing advertising in the games of console (Kerr, 2003).

It stands out that children and pre-teenagers, do not differentiate and do not give importance to the language of digital media contents: Spanish and Catalan.

\section{Conclusion}

The digital media convergence is present in the everyday life of the Catalan children, accustomed to engage with their preferred contents. However, there is a lack of quantitative and qualitative studies that describe the consumption of contents and devices by children in Catalonia. As a result of this study we can conclude:

- The way in which Catalan children and pre-teenagers watch, share, discuss and interact with digital media is evolving. This can bring a strong change for the TV.

- Children's enthusiastic embrace of new media has resulted in a steady increase in hours of screen time, with digital use largely in addition to television viewing.

- Among children this behavior is now an integral part of their lives - they are born into a digital world and have never known a time without the internet affecting all aspects of their daily life.

- But on occasions, they prefer to focus exclusively on just one screen, also discriminate in their media use or exclusive use.

- $\quad$ Pre-teenagers are more likely than children to be multitasking, paving the way for an entirely new approach to media consumption. 
- As a final reflection, we propose a couple of recommendations for future investigations in the same line of the project:

- The need to get deeper into the study of the digital media convergence in the group of the digital native, especially because in a not distant future they will represent the social majority.

- In studies of this type it is necessary to introduce other variables: socioeconomic level, language of each of the consumed contents (Catalan or Spanish), and educational level of the parents. This variables would improve notably the results to show a more complete reality.

- $\quad$ It is not easy to assess the time of use of the media especially between the younger group, interviews or focus group with children they should be compared with the answers of the parents.

- The use of focus groups is the more simple way to access to children as subjects for interviews as it can be difficult to obtain consent from parents.

\section{References}

AIMC-EGM-AGENCIA CATALANA DEL CONSUM (2011). Els joves $i$ les Tic d'acces a l'entorn virutal. Estudis sobre els hàbits de consum dels joves de Catalunya. Col-lecció Estudis. [https://www.consum.cat/documentacio/14016.pdf] Accessed: 20.09.2013.

BRINGUÉ, Xavier; SÁDABA Charo. (2011). Menores y redes sociales. Foro Generaciones Interactivas. Madrid: Fundación Telefónica. [http://www.generacionesinteractivas.org/?p=2892] Accessed: 20.03.2011.

BRINGUÉ, Xavier; SÁDABA Charo. (2009). La Generación Interactiva en España. Niños y adolescentes ante las pantallas. Madrid: Colección Fundación Telefónica. Ariel. [http://www.osimga.gal/export/sites/osimga/gl/documentos/d/BringueSadaba_Generacion-interactiva-espana-1.pdf] Accessed: 21 04.2013.

CONTRERAS-ESPINOSA, Ruth, Sofia; GARCÍA, Irene; GONZÁLEZ, Zahaira; MASSANA, Eulalia; NAVARRO, Héctor. (2011). Convergència mediática digital: El consum de continguts i l'ús de nous mitjans per dones a Catalunya. Barcelona: Institut Català de les Dones. [http://www.recercat.cat/handle/10854/2442] Accessed: 21.04.2013.

GARCÍA-JIMÉNEZ, Antonio; LÓPEZ DE AYALA, Maria; CATALINA-GARCÍA, Beatriz (2013). Hábitos de uso en Internet y en las redes sociales de 
los adolescentes españoles. En: Revista Comunicar, $\mathrm{n}^{\circ}$ 41, vol. 2, pp. 195204. [http://dx.doi.org/10.3916/C41-2013-19] Accessed: 21.04.2014.

GARMENDIA, M., GARITAONANDIA, C., MARTÍNEZ, G. ; CASADO, M. A. (2011). Riesgos y seguridad en internet: Los menores españoles en el contexto europeo. Universidad del País Vasco/Euskal Herriko Unibertsitatea, Bilbao: [EU Kids Online. http://www.lse.ac.uk/media@1se/research/EUKidsOnline/EU\%20 Kids\%20II\%20(2009-11)/National\%20reports/Spanish\%20report.pdf] Accessed: 21.04 .2014 .

GRODAL, Torben (2000). Video games and the pleasure of control. En: ZILLMAN, Dolf y VORDERER, Peter (eds.) Media entertainment: The psychology of its appeal. Mahwah, NJ: Lawrence Erlbaum, p. 197-213.

IVORY, James (2006). Still a Man's Game: Gender Representation in Online Reviews of Video Games. En: Mass Communication and Society, ${ }^{\circ}$ 9, vol.1, pp.103-114.

LIVINGSTONE, Sonia; BRAKE, David. (2010). On the Rapid Rise of Social Networking Sites: New Findings and Policy Implications. Children \& Society, $\mathrm{n}^{\mathrm{o}}$ 24, pp. 75-83. [http://dx.doi.org/10.1111/j.1099-0860.2009.00243.x] Accessed: 21.04.2014.

LIVINGSTONE, Sonia, HADDON, Leslie, GÖRZIG, Anke, ; ÓLAFSSON, Kjar$\tan (2011)$. Risks and Safety on the Internet: The Perspective of European Children. Full Findings. LSE, London: EU Kids Online. [http://www.lse.ac.uk/ media\%401se/research/EUKidsOnline/EU\%20Kids\%20II\%20(2009-11)/EUKidsOnlineIIReports/D4FullFindings.pdf] Accessed: 21.04.2014.

KERR, Aphra. (2003). Girls/Women Just Want to Have Fun. A Study of Adult Female Players of Digital Games. En: Level Up Conference Proceedings. University of Utrecht, pp. 270-285. [http://eprints.nuim.ie/1232/1/DIGRA_04_akerr.pdf] Accessed: 11.05.2011.

MADEN, Mary; CORTESI, Sandra; GASSER, Urs; LENHART, Amanda; DUGGAN, Maeve. (2012). Parents, Teens, and Online Privacy. Pew Internet \& American Life Project. Report Nov 20. [http://www.pewinternet.org/files/old-media// Files/Reports/2012/PIP_ParentsTeensAndPrivacy.pdf] Accessed: 15.11.2013.

MORENO, Isidro, GARCÍA, José Antonio. (2006). Nuevas pantallas: otras formas de comunicar en el siglo XXI. Revista Educatio siglo XXI, n 24, pp. 123-150. [http://revistas.um.es/educatio/article/view/158] Accessed: 15.11.2013.

NAVARRO-GUERE, Héctor; GONZÁLEZ, Zahaira, MASSANA, Eulalia, GARCÍA, Irene, CONTRERAS-ESPINOSA, Ruth S. (2011). Pantalles, continguts $i$ usuaris. Panorama de la convergència mediàtica digital, els continguts i el consum a Catalunya. Barcelona: Consell de l'Audiovisual de Catalunya. [https:// www.cac.cat/pfw_files/cma/recerca/estudis_recerca/Consum_multipantalla.pdf] Accessed: 10.11.2014.

PÉREZ TORNERO, José Manuel; PULIDO, Cristina. (2012). Infància i TIC a Catalunya: la bombolla mediática d'infants i adolescents. UNICEF Comitè Catalunya. [https://www.unicef.es/sites/www.unicef.es/files/DOCS-MITJANS_COMUNICACIO.pdf] Accessed: 10.11.2014.

RUANO, Soledad. (2010). Internet y la telefonía móvil. Nuevos soportes para distribuir contenidos audiovisuales. Revista Razón y Palabra, no 68. [http://www. razonypalabra.org.mx/N/n68/varia/ruano.html] Accessed: 12.02.2015. 
SÁNCHEZ, Adolfo; FERNÁNDEZ Maria. (2010). Informe generación 2.0. Hábitos de los adolescentes en el uso de las redes sociales. Estudio comparativo entre Comunidades Autónomas. Universidad Camilo José Cela. Madrid. [http://estaticos. elmundo.es/documentos/2010/07/06/Generacion20.pdf] Accessed: 02.06.2015.

RIDEOUT, Vicky. (2011).Zero to Eight: Children's Media Use in America. Common Sense Media Research Study. October 25. [https://www.commonsensemedia. org/research/zero-to-eight-childrens-media-use-in-america/key-finding-1\%3Ayoung-children-use-digital-media-frequently\#] Accessed: 02.06.2015.

ROCA, Meritxell; ARANDA, Daniel; SÁNCHEZ, Jordi (2012) Convergència mediàtica i joves. Usos, espais i estratègies de mediació familiar en el consum audiovisual dels adolescents catalans. Barcelona: Internet Interdisciplinary Institute. [http://www.in3.cat/opencms_portalin3/opencms/en/publicacions/informes/ index $\cdot$ html? resultsPerPage $=50 \&$ displayPages $=10 \&$ currentPage $=2]$ Accessed: 21.04.2013.

VALKENBURG, Patti \& PETER, Jochen (2011). Online Communication among Adolescents: An integrated model of its attraction, opportunities, and risks. Journal of Adolescent Health, $\mathrm{n}^{\mathrm{o}}$ 48, vol.2, pp.121-127. [http://dx.doi.org/10.1016/j. jadohealth.2010.08.020] Accessed: 11.10.2015. 